\title{
PENGARUH TINGKAT KONSENTRASI GULA PADA PROSES PENGOLAHAN MANISAN SALAK TERHADAP VITAMIN C DAN TINGKAT KESUKAAN KONSUMEN
}

\author{
Influence of Sugar Concentration in Processing Zallaca Sweet on Vitamin C and Consumers \\ Preference
}

\section{Syane Palijama*, Josephina Talahatu, dan Priscillia Picauly}

\author{
Jurusan Teknologi Hasil Pertanian, Fakultas Pertanian, Universitas Pattimura, Ambon \\ Jl. Ir. M. Putuhena Kampus Poka Ambon 97233 \\ * Penulis Korespondensi: E-mail: annie_jeane@yahoo.com
}

\begin{abstract}
Fruit of zallaca (Salacca edulis Reinw) can be made as food product. One of these products is zallaca sweet by using sugar as sweetener and preservative. The objective of the research was to study and determine sugar concentration level to maintain quality of zallaca sweet product. A complete randomized design was used in the research. A compeletely randomized design was used with eight treatments sugar concentration as follows $25,30,35,40,45,50,55$, and $60 \%$ of sugar concentration. Result showed that using of $40 \%$ sugar could maintain the quality of zallaca sweet with concentration of vitamin $\mathrm{C} 0.033 \mathrm{mg}$, moisture content $76.56 \%$, total acid $3.12 \%$, total sugar $18,13 \%$ and $\mathrm{pH} 4.5$.
\end{abstract}

Keywords: salacca, sweetener, vitamin C, consumers preference

\begin{abstract}
ABSTRAK
Salak (Salacca edulis Reinw) dapat diolah menjadi berbagai produk makanan. Salah satu diantaranya adalah manisan salak yang menggunakan gula sebagai bahan pemanis juga sebagai pengawet. Penelitian ini bertujuan untuk mempelajari dan menentukan tingkat konsentrasi gula yang tepat dalam mempertahankan mutu produk manisan salak. Rancangan yang digunakan adalah Rancangan Acak Lengkap dengan delapan perlakuan konsentrasi gula yaitu konsentrasi gula 25, 30, 35, 40, 45, 50, 55, dan 60\%. Hasil penelitian menunjukkan bahwa penggunaan konsentrasi gula $40 \%$ dapat mempertahankan mutu manisan salak dengan kandungan vitamin C $0,033 \mathrm{mg}$, kadar air 76,56\%, total asam 3,12\%, total gula $18,13 \%$, pH 4,5.
\end{abstract}

Kata kunci: salak, manisan, vitamin C, tingkat kesukaan konsumen

\section{PENDAHULUAN}

Salak merupakan salah satu jenis buahbuahan yang memiliki sifat mudah rusak dan tidak tahan lama. Namun buah salah memiliki kandungan gizi yang cukup tinggi, diantaranya karbohidrat, protein, kalisum, fosfor dan zat besi (Maulidiah et al., 2014). Oleh karena itu perlu dilakukan pengolahan dengan maksud untuk memperpanjang masa simpan, meningkatkan nilai jualnya dan penganekaragaman pangan. Salah satu jenis pengolahan buah salak yaitu menjadi manisan
Manisan adalah buah atau sayur yang diawetkan menggunakan gula dengan kadar yang tinggi untuk memberikan atau menambahkan rasa manis dan mencegah pertumbuhan mikroorganisme (Septya et al., 2017).

Penggunaan larutan gula dengan kadar yang tinggi pada bahan pangan akan meningkatkan tekanan osmosis yang dapat mencegah pertumbuhan mikroba sehingga bahan akan menjadi lebih awet. Selain itu, penggunaan larutan gula yang tinggi dapat menyebabkan sebagian air yang ada menjadi tidak tersedia untuk pertumbuhan mikroorganisme dan aktivitas air $\left(\mathrm{a}_{\mathrm{w}}\right)$ dari bahan 
akan menurun. Hal ini disebabkan karena gula bersifat mengikat air sehingga berfungis sebagai pengawet (Buckle et al., 2007).

Gula merupakan bahan tambahan yang dipakai dalam proses pengolahan bahan pangan, yang terdiri dari glukosa, fruktosa, maltosa, sukrosa dan laktosa yang mempunyai sifat fisik dan kimia berbeda-beda misalnya dalam hal rasa manisnya. Gula yang dipakai dalam pembuatan manisan umumnya yaitu gula sukrosa. Penggunaan gula pasir pada proses pembuatan produk makanan berfungsi untuk memberikan rasa manis dan sebagai pengawet (Muchtadi, 2011).

\section{METODE PENELITIAN}

\section{Bahan}

Bahan-bahan yang digunakan dalam pembuatan manisan salak adalah salak dan gula pasir. Sebagian besar bahan-bahan dibeli dari pasar lokal di Kota Ambon.

\section{Pembuatan Manisan Salak}

Buah salak dipilih yang baik dan tua kemudian sisihkan buah yang busuk dan kupas kulit luarnya yang kasar, begitu juga kulit ari daging buah dibelah, biji dibuang selanjutnya potongan daging buah dibentuk menurut selera. Pencucian dilakukan pada potongan daging buah tersebut hingga bersih selanjutnya buah direndam dalam larutan garam selama $12 \mathrm{jam}$. Setelah perendaman potongan daging buah dicuci dengan air hangat, air ditiriskan kemudian buah salak dimasukan ke dalam stoples setelah itu dituangkan larutan gula sesuai dengan perlakuan yaitu konsentrasi gula $25 \%, 30 \%, 35 \%, 40 \%, 45 \%, 50 \%$, 55\%, dan $60 \%$. Larutan gula dituang sedikit demi sedikit hingga semua daging buah terendam.

\section{Pengamatan}

Pengamatan dilakukan setelah selesai proses pembuatan manisan salak dan analisa dilakukan terhadap vitamin C (AOAC, 1995), total asam (AOAC, 1995), kadar air (AOAC, 1995), total gula (AOAC, 1995), pH, dan Uji organoleptik meliputi rasa, tekstur dan tingkat kesukaan.

\section{Rancangan Percobaan dan Analisis Statistik}

Percobaan dilakukan dengan metode rancangan acak lengkap dengan delapan taraf perlakuan dan dua kali ulangan. Analisis keragaman digunakan untuk menganalisis data yang diperoleh dengan menggunakan software Minitab 16. Jika terdapat beda nyata maka analisis dilanjutkan dengan uji Tukey $(\alpha=0,05)$.

\section{HASIL DAN PEMBAHASAN}

\section{Vitamin C}

Hasil penelitian menunjukkan bahwa perlakuan konsentrasi gula 25\%, 30\% dan 35\% memiliki kandungan vitamin $\mathrm{C}$ yang stabil, yaitu 0,035 mg, sedangkan pada perlakuan konsentrasi gula $40,45,50,55$, dan $60 \%$ terjadi penurunan kandungan vitamin $\mathrm{C}$, karena penambahan gula dengan konsentrasi yang berbeda, dimana semakin tinggi konsentrasi gula maka semakin rendah kandungan vitamin $\mathrm{C}$ pada manisan salak. Penggunaan gula dalam hal ini sukrosa akan terhidrolisa menjadi fruktosa sehingga dapat mempercepat jalannya proses degradasi vitamin $\mathrm{C}$, sehingga mengalami penurunan.

Hasil yang sama juga ditunjukkan oleh Septya et al. (2017) dimana penggunaan gula yang tinggi menyebabkan kadar vitamin $\mathrm{C}$ pada manisan basah batang daun pepaya semakin menurun. Menurut Kartika dan Nisa (2015), proses perendaman pada pembuatan manisan dengan konsentrasi gula yang tinggi menyebabkan terjadinya peristiwa osmosis, dimana air yang keluar dari dalam bahan akan semakin banyak sehingga kehilangan vitamin $\mathrm{C}$ akan semakin besar. Hal ini terjadi karena sifat alami dari vitamin $\mathrm{C}$ yang larut dalam air.

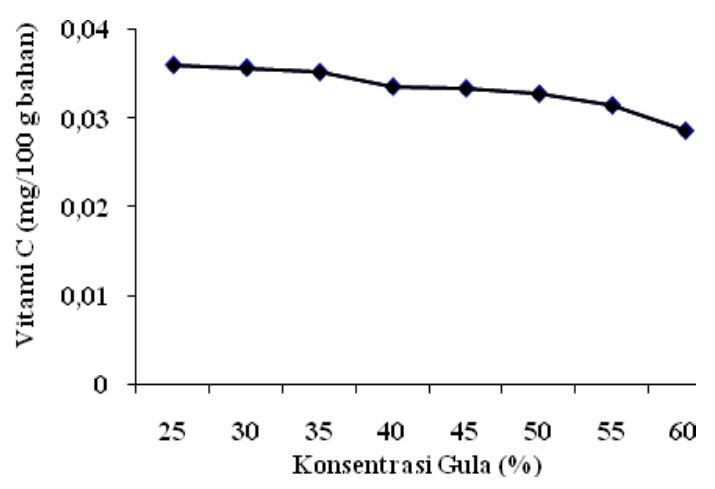

Gambar 1. Vitamin C manisan salak 


\section{Total Asam}

Hasil penelitian terhadap total asam manisan salak menunjukkan bahwa terjadi peningkatan total asam pada setiap perlakuan, dimana nilai total asam yang tertinggi yaitu $3,51 \%$ dengan tingkat konsentrasi gula $60 \%$ sedangkan nilai total asam terendah yaitu 2,87\% dengan tingkat konsentrasi gula $25 \%$. Hal ini disebabkan karena adanya penambahan konsentrasi gula pada setiap perlakuan, dimana sukrosa mengalami penguraian sehingga asam akan timbul dan jumlahnya bertambah, sejalan dengan kadar gula yang tinggi, dengan kata lain kadar gula yang tinggi bersama dengan kadar asam yang tinggi ( $\mathrm{pH}$ rendah). Menurut Winarno (2004) bahwa dalam pemecahan dan dehidrasi serta diikuti dengan polimerisasi, dan beberapa jenis asam akan timbul sebagai akibat penguraian sukrosa dalam campuran tersebut. Hal ini juga sejalan dengan pendapat Buckle et al. (2007) bahwa gula dapat dipakai sebagai salah satu kombinasi dari teknik pengawetan bahan pangan dalam hal ini manisan salak, dimana ada hubungan keterikatan yaitu kadar gula yang tinggi sejalan dengan kadar asam yang tinggi ( $\mathrm{pH}$ rendah). Dengan demikian semakin bertambahnya tingkat konsentrasi gula akan bertambahnya total asam pada produk manisan salak. Kadar gula yang tinggi maka kadar asam akan tinggi sehingga akan terjadi penurunan nilai $\mathrm{pH}$ yaitu nilai $\mathrm{pH}$ rendah.

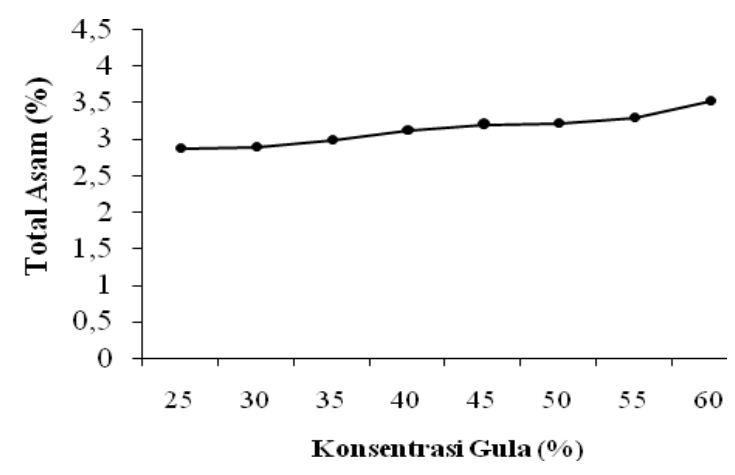

Gambar 2. Total asam manisan salak

\section{pH}

Hasil penelitian dari $\mathrm{pH}$ produk manisan salak (Gambar 3), menunjukkan bahwa perlakuan konsentrasi gula $25 \%$ memiliki nilai $\mathrm{pH}$ tertinggi yaitu 4,7 dan perlakuan konsentrasi gula $60 \%$ memiliki nilai $\mathrm{pH}$ terendah yaitu 4,4 . Hal ini jika dibandingkan dengan nilai $\mathrm{pH}$ pada buah salak hasil analisa awal yaitu 4,3. Dengan demikian terjadi peningkatan $\mathrm{pH}$ akibat perlakuan konsentrasi gula namun pada setiap perlakuan terjadi penurunan nilai $\mathrm{pH}$. Hal ini disebabkan karena penambahan konsentrasi gula pada setiap perlakuan. Hal ini dapat dijelaskan bahwa nilai $\mathrm{pH}$ dan total asam mempunyai hubungan timbal balik dan saling mempengaruhi, dimana bila nilai $\mathrm{pH}$ meningkat maka diikuti dengan menurunnya total asam atau sebaliknya.

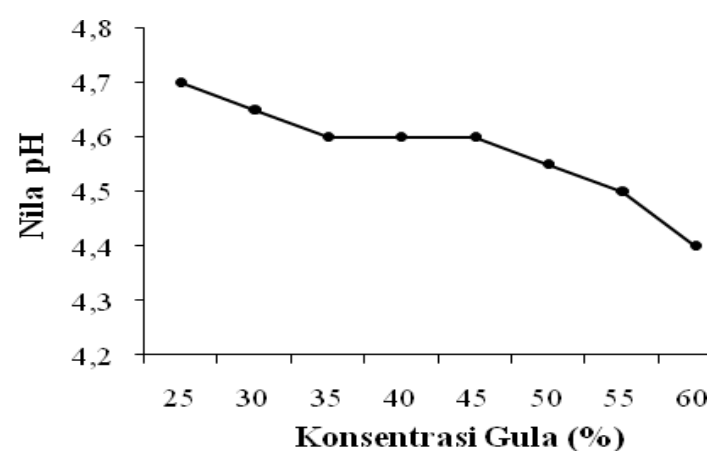

Gambar 3. Nilai pH manisan salak

\section{Total Gula}

Pada Gambar 4 terlihat bahwa tingkat konsentrasi gula $60 \%$ mempunyai kandungan total gula tertinggi yaitu $21,73 \%$, sedangkan kandungan total gula terendah yaitu $16,02 \%$ pada perlakuan konsentrasi gula 25\%. Dengan demikian terjadi peningkatan total gula yang disebabkan karena penambahan konsentrasi gula, hal ini disebabkan karena adanya penetrasi gula, dimana gula mengikat air sehingga gula menempati pori-pori tempat air tersebut pada daging manisan salak.

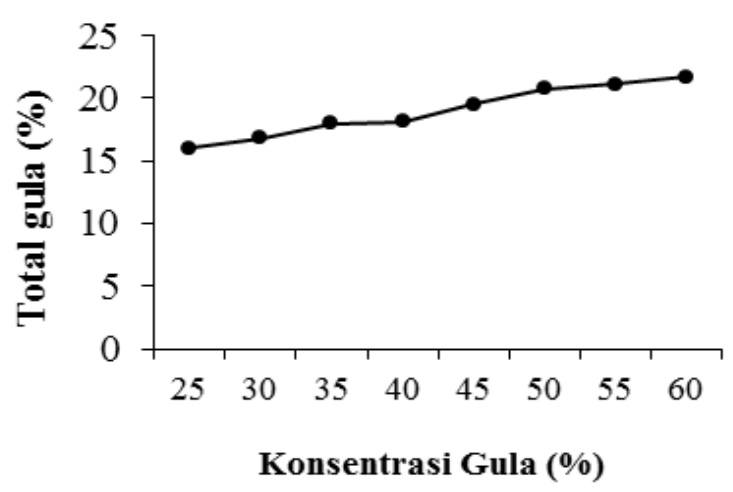

Gambar 4. Total gula manisan salak 
Menurut Kartika dan Nisa (2015), peningkatan jumlah sukrosa pada produk terjadi karena semakin besarnya peristiwa difusi yang disebabkan oleh semakin besarnya jumlah sukrosa yang ditambahkan, sehingga besarnya jumlah gula yang terukur akan semakin besar.

\section{Kadar Air}

Hasil penelitian untuk kadar air manisan salak menunjukkan bahwa perlakuan konsentrasi gula 25\% memiliki kandungan air tertinggi yaitu $79,50 \%$, sedangkan kandungan air terendah pada perlakuan konsentrasi gula $60 \%$ yaitu $73,97 \%$. Jika dibandingkan dengan nilai kadar air pada buah salak hasil analisa awal yaitu $81,45 \%$. dengan demikian terjadi penurunan nilai kadar air pada produk manisan salak. Hal ini disebabkan karena penambahan konsentrasi gula pada tiap-tiap perlakuan. Pada konsentrasi gula 25\% dan 30\% kandungan airnya masih tinggi, hal ini disebabkan karena perlakuan konsentrasi gula 25\% dan $30 \%$ rendah sehingga gula belum mengikat air dengan maksimal. Selanjutnya pada perlakuan konsentrasi gula $35 \%, 40 \%, 45 \%, 50 \%, 55 \%$ dan $60 \%$ mengalami penurunan sampai mencapai nilai terendah yaitu $73,96 \%$. Hal ini disebabkan karena penyerapan gula sudah normal dimana air dalam bahan sudah keluar dan gula telah menempati tempat air, dengan demikian air dalam manisan salak tidak tersedia sehingga jumlahnya menjadi berkurang.

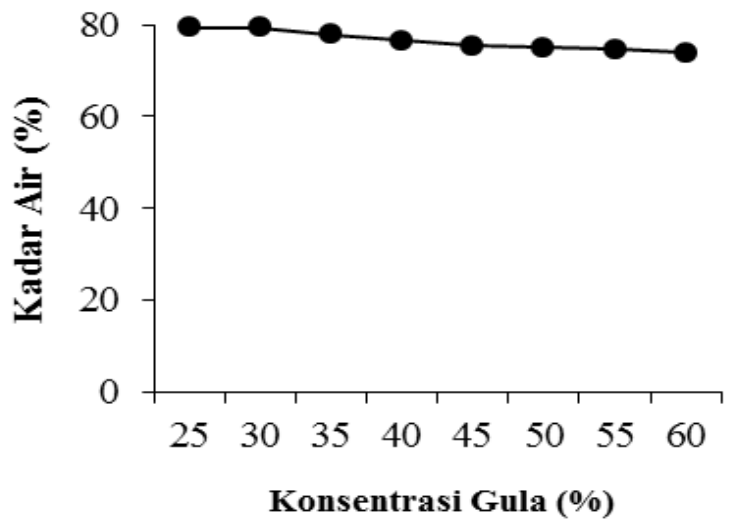

Gambar 5. Kadar air manisan salak

Penurunan kadar air pada produk manisan salak, berkaitan erat dengan kenaikan total gula produk, kenaikan total gula akan mempengaruhi keseimbangan air, maka persentase kandungan air dalam produk akan berkurang. Menurut Sohibulloh et al. (2013), penambahan gua dalam jumlah banyak dapat mengakibatkan proses dehidrasi osmosis sehingga sejumlah air akan keluar dari buah-buahan. Kepekatan konsentrasi gula yang semakin tinggi menyebabkan jumlah air yang keluar dari bahan juga semakin banyak.

\section{Rasa}

Hasil uji menunjukkan bahwa perlakuan tingkat konsentrasi gula memberikan pengaruh yang nyata terhadap rasa manisan salak, dimana pada perlakuan konsentrasi gula $25 \%$ memiliki nilai rasa tertinggi yaitu 3,20 dan konsentrasi gula 60\% memiliki nilai terendah yaitu 2,27. Dengan demikian ini membuktikan bahwa perlakuan tingkat konsentrasi gula sangat berpengaruh terhadap nilai rasa daripada produk manisan salak.

Dari 15 panelis yang mencicipi manisan salak ternyata pada konsentrasi gula 25\%,30\% dan $35 \%$ rata-rata menyatakan manisan salak agak sepat dengan nilai 3,20, 2,79 dan 2,64. Sedangkan pada konsentrasi gula $40 \%, 45 \%, 50 \%, 55 \%$ dan $60 \%$ rata-rata tidak sepat oleh panelis terhadap rasa manisan salak dengan nilai 2,37, 2,36, 2,36, 2,35, dan 2,27.

Setiap perlakuan, disertai dengan tingkat konsentrasi gula mengakibatkan nilai rasa setiap perlakuan mengalami perubahan yaitu nilai tertinggi pada perlakuan konsentrasi gula 25\% memiliki rasa sepat yang tinggi sedangkan pada perlakuan konsentrasi gula $60 \%$ memiliki rasa sepat yang rendah. Dengan demikian setiap penambahan konsentrasi gula akan berpengaruh terhadap rasa dari produk manisan salak yaitu rasanya akan manis disertai dengan hilangnya rasa sepat yang dalam hal ini terdapat kandungan zat tanin dalam daging manisan salak.

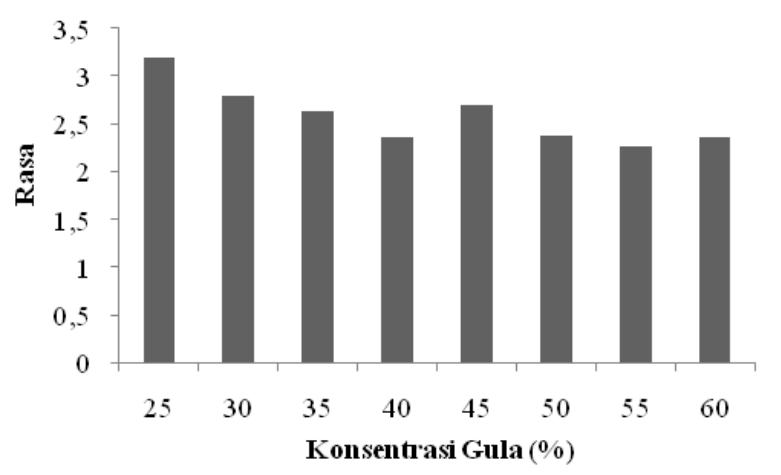

Gambar 6. Rasa manisan salak 


\section{Tingkat Kesukaan}

Pada hasil uji tingkat kesukaan manisan salak menunjukkan bahwa pengaruh konsentrasi gula $25 \%, 30 \%, 35 \%, 40 \%, 45 \%, 55 \%$ dan $60 \%$ tidak memberikan pengaruh yang nyata. Dari 15 panelis yang mencicipi, ternyata rata-rata menyatakan suka terhadap tingkat kesukaan manisan salak dengan nilai terendah 3,07 dan nilai tertinggi 3,83 (Gambar 7).

\section{Tekstur}

Pada hasil uji tekstur manisan salak menunjukkan bahwa pengaruh konsentrasi gula $25 \%, 30 \%, 35 \%, 40 \%, 45 \%, 55 \%$ dan $60 \%$ tidak memberikan pengaruh yang nyata. Dari 15 panelis yang mencicipi ternyata tekstur manisan salak agak keras dengan nilai terendah 2,47 dan nilai tertinggi 3,10 . jika dilihat pada Gambar 8 bahwa pada setiap perlakuan terjadi penurunan nilai tekstur.

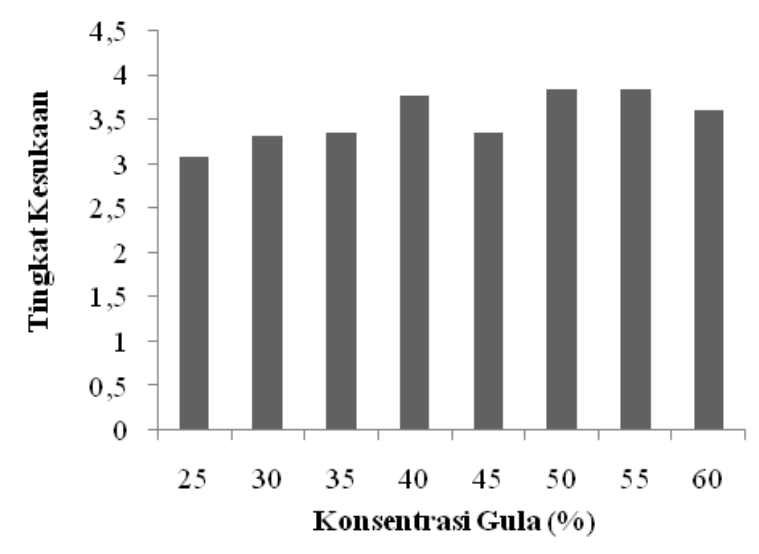

Gambar 7. Tingkat kesukaan manisan salak

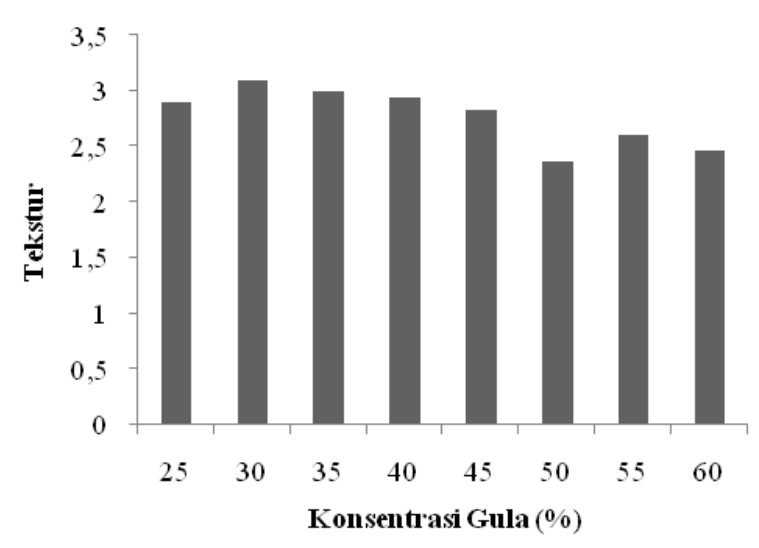

Gambar 8. Tekstur manisan salak

\section{KESIMPULAN}

Perlakuan konsentrasi gula $40 \%$ dapat mempertahankan mutu manisan salak dengan vitamin C 0,033 mg, kandungan air 76,557\%, total asam $3,117 \%$, total gula $18,127 \%, \mathrm{pH} 4,599$, dan juga dapat memberikan rasa tidak sepat (manis) pada manisan salak.

\section{DAFTAR PUSTAKA}

[AOAC] Association of Official Analytical Chemistry. 2002. Official Method of Analysis. Washington. D.C.

Buckle, K.A, R.A. Edwards, G.H. Fleet, and M. Wooton. 2007. Ilmu Pangan. Penerjemah: H. Purnomo dan Adiono. Universitas Indonesia Press. Jakarta.

Kartika, P.N. dan F.C. Nisa. 2015. Studi pembuatan osmodehidrat buah nenas (Ananas comosus L. Merr); kajian konsentrasi gula dalam larutan osmosis dan lama perendaman. Jurnal Pangan dan Agroindustri 3: 13451355.

Maulidiah, A., D. Hidayati, dan S. Hastuti. 2014. Analisa karakteristik manisan kering salak (Salacca edulis) dengan lama perendaman dan konsentrasi larutan gula. Jurnal Agrointek 8: 23-31.

Muchtadi, D. 2011. Karbohidrat Pangan dan Kesehatan. Alfabeta. Bandung.

Septya, S., I. Suhaidi, dan Ridwansyah. 2017. Pengaruh konsentrasi gula dan lama penyimpanan terhadap mutu manisan basah batang daun pepaya. Ilmu dan Teknologi Pangan 5: 73-80.

Sohibulloh, I., D. Hidayati, dan Burhan. 2013. Karakteristik manisan nangka kering dengan perendaman gula bertingkat. Jurnal Agrointek 7: 84-89.

Winarno, F.G. 2004. Kimia Pangan dan Gizi. Gramedia Pustaka Utama. Jakarta. 